Article

\title{
Biomass-Derived Carbonaceous Adsorbents for Trapping Ammonia
}

\author{
Chibi A. Takaya ${ }^{1}$, Kiran R. Parmar ${ }^{1} @$, Louise A. Fletcher ${ }^{2}$ and Andrew B. Ross ${ }^{1, *}$ \\ 1 Centre for Integrated Energy Research, School of Chemical and Process Engineering, University of Leeds, \\ Leeds LS2 9JT, UK; chibitakaya@yahoo.com (C.A.T.); pmkpa@leeds.ac.uk (K.R.P.) \\ 2 School of Civil Engineering, University of Leeds, Leeds LS2 9JT, UK; L.A.Fletcher@leeds.ac.uk \\ * Correspondence: A.B.Ross@leeds.ac.uk; Tel.: +44-(0)113 3431017
}

Received: 16 November 2018; Accepted: 5 January 2019; Published: 9 January 2019

check for updates

\begin{abstract}
The preparation of low-cost carbonaceous adsorbents for nitrogen recovery is of interest from agricultural and waste management perspectives. In this study, the gaseous ammonia $\left(\mathrm{NH}_{3}\right)$ and aqueous ammonium $\left(\mathrm{NH}_{4}{ }^{+}\right)$sorption capacities have been measured for different types of carbonaceous chars produced under different conditions. The study includes a comparison of an oak-based hydrochar produced from hydrothermal carbonisation (HTC) at $250{ }^{\circ} \mathrm{C}$ with two biochars produced from slow pyrolysis at $450{ }^{\circ} \mathrm{C}$ and $650{ }^{\circ} \mathrm{C}$, respectively. The chars were also chemically modified with $\mathrm{H}_{2} \mathrm{SO}_{4}, \mathrm{H}_{3} \mathrm{PO}_{4}, \mathrm{H}_{2} \mathrm{O}_{2}$, and $\mathrm{KOH}$ to investigate the potential for sorption enhancement. The highest sorption capacities for $\mathrm{NH}_{3}$ were observed for the hydrochars with typical uptake capacities ranging from $18-28 \mathrm{mg} \mathrm{g}^{-1} \mathrm{NH}_{3}$. Sorption capacity for oak biochars is significantly lower and ranges from $4-8 \mathrm{mg} \mathrm{g}^{-1}$ for biochars produced at $450{ }^{\circ} \mathrm{C}$ and $650{ }^{\circ} \mathrm{C}$, respectively. Hydrochar showed a substantially higher sorption capacity for $\mathrm{NH}_{3}$ despite its lower surface area. The $\mathrm{CaCl}_{2}$ extractable $\mathrm{NH}_{4}{ }^{+}$following ammonia adsorption is incomplete. Typically, only $30-40 \%$ of the $\mathrm{N}$ is released upon washing with $\mathrm{CaCl}_{2}$ in form of $\mathrm{NH}_{4}{ }^{+}$. Post chemical modification of the chars resulted in only limited enhancement of char $\mathrm{NH}_{3}$ and $\mathrm{NH}_{4}{ }^{+}$sorption. $\mathrm{H}_{3} \mathrm{PO}_{4}$ treatment showed the greatest potential for increasing $\mathrm{NH}_{3} / \mathrm{NH}_{4}{ }^{+}$sorption in biochars, while $\mathrm{KOH}$ and $\mathrm{H}_{2} \mathrm{O}_{2}$ treatment increased $\mathrm{NH}_{3}$ sorption in the hydrochar. As only marginal increases to char surface area were observed following char treatment, these findings suggest that char surface functionality is more influential than surface area in terms of char $\mathrm{NH}_{3} / \mathrm{NH}_{4}{ }^{+}$sorption.
\end{abstract}

Keywords: hydrochar; biochar; activation; ammonia; ammonium; adsorption

\section{Introduction}

Nitrogen species are present in several agricultural and industrial wastewater effluents, where excessive quantities contribute to eutrophication. Furthermore, $\mathrm{NH}_{3}$ emission into the atmosphere can result in nutrient deposition in nutrient sensitive ecosystems, formation of light-scattering aerosols resulting in haze, and visibility impairment and formation of inhalable aerosol particles which have health concerns [1]. Activated carbon has been the standard adsorbent used for recovering a variety of species owing to its well-developed pore structure and high surface area [2-4]. However, due to the high costs associated with traditional activated carbon, alternative waste-derived feedstocks have been considered, ranging from agricultural by-products and industrial waste materials $[2,3]$. Subsequent thermal and/or chemical activation of such feedstocks via incorporation of metal salts or oxidizing agents result in more cost-effective adsorbents [3,5]. To be considered suitable however, such alternative feedstocks are required to be abundant, carbon-rich, and possess appreciable pore development [3]. 
Hydrochars and biochars show potential as suitable alternatives to traditional activated carbon as they are carbon-rich and can be produced from a wide range of feed-stock although they are likely to require modification to enhance their nutrient sorption capacities [6]. Studies have demonstrated that adsorption using biochar is roughly consistent with Langmuir and Freundlich adsorption isotherm models, although uncertainty in adsorption mechanisms exist due to different pyrolysis reaction conditions and the fact that the presence of Brønsted and/or Lewis acid sites on the adsorbent surfaces enhance $\mathrm{NH}_{3}$ sorption $[7,8]$. In the former case, protonation of $\mathrm{NH}_{3}$ occurs as $\mathrm{NH}_{3}$ dissociates in water or via acid-base neutralization reactions with carbonyl and phenolic $\mathrm{OH}^{-}$groups to form $\mathrm{NH}_{4}{ }^{+}$complexes [4,5,9-11]. Conversely, the donation of lone pair electrons from $\mathrm{N}$ atoms to cationic adsorbent sites such as metal species can occur at Lewis acid sites [9,10,12,13]. $\mathrm{NH}_{3}$ adsorption capacities have been studied for various biochars and have reported no direct correlation of pyrolysis reaction temperature or significance of surface area once activated [14,15]. Moreover, $\mathrm{NH}_{4}{ }^{+}$adsorption capacities have been reported to be greater in biochars produced at low temperatures between 300 to $400{ }^{\circ} \mathrm{C}$, possibly due to their higher proportion of acid functional groups $[16,17]$ including high $\mathrm{pH}$ [18]. However, a study also found biochars with higher $\mathrm{NH}_{4}{ }^{+}$adsorption capacities with increasing pyrolysis temperatures [19]. Though, different feedstock materials were used in the preparation of the biochars examined.

These studies have shown that biochar sorption mechanisms still require further investigation and suggest that hydrochars from the hydrothermal carbonisation (HTC) process are likely to possess greater ability for $\mathrm{NH}_{3} / \mathrm{NH}_{4}{ }^{+}$sorption compared to biochars, given their higher proportion of acidic functional groups. On the other hand, the higher surface areas of biochars may compensate for their lower acidic functionalities since some studies have reported that high adsorbent surface areas and pore volumes increase $\mathrm{NH}_{3} / \mathrm{NH}_{4}{ }^{+}$removal efficiencies $[10,19,20]$. Moreover, the high surface areas of some biochars may provide more sites for the loading of acidic or cationic species which increase the number of Brønsted and Lewis acid sites respectively.

Studies in the literature directly comparing ammonia sorption of hydrochar and biochar are limited and show mixed results. An emissions and growth study showed that hydrochar lowered $\mathrm{NH}_{3}$ emissions compared to biochar which was attributed to the greater acidity of hydrochar [21]. Contrarily, it was found that hydrochar and biochar increased the emissions of $\mathrm{NH}_{3}$ when applied as a soil amender with the addition of pig slurry. Moreover, hydrochar had a reduced ability to absorb $\mathrm{NH}_{4}{ }^{+}$, which was attributed to its increased hydrophobicity and $\mathrm{pH}$ buffering capabilities [22]. Both studies used the same hydrochar and biochar production approach and both used Miscanthus as a feedstock although it is speculated that the production of hydrochar was not performed in subcritical water but was rather steam treated, akin to the autoclaving process.

This study is therefore aimed at contributing to the growing research on factors influencing char $\mathrm{NH}_{3}$ and $\mathrm{NH}_{4}{ }^{+}$sorption. In particular, understanding the difference in behaviour between hydrochar and biochar and investigating the potential for enhancing sorption using post chemical modification. Owing to their low levels of contaminants, hydrochar and biochars derived from bark-free holm oak wood were evaluated before and after treatment with various chemical agents. It is anticipated that this study will contribute to growing research on the factors influencing nitrogen recovery by adsorbents derived from a wider range of agricultural residues.

\section{Materials and Methods}

\subsection{Materials}

Oak hydrochar was produced using a $600 \mathrm{~mL}$ stainless steel Parr 4836 bench-top reactor (Parr, Moline, IL, USA) by heating $10 \mathrm{wt} \%$ bark-free holm oak wood (particle size $<1 \mathrm{~mm}$ ) in distilled water at $250^{\circ} \mathrm{C}$ for $1 \mathrm{~h}$ at autogenous pressure (approximately $4 \mathrm{MPa}$ ). The reactor and its contents were allowed to cool to about $50^{\circ} \mathrm{C}$ before recovering the resulting hydrochar from the process water by filtration followed by air-drying. The hydrochar was designated as Oak 250. Biochars were supplied 
and produced from Oak wood (particle size $<2 \mathrm{~mm}$ ) were obtained from a commercial pyrolysis plant operated by Proininso S.A. (Málaga, Spain) at $450{ }^{\circ} \mathrm{C}$ and $650{ }^{\circ} \mathrm{C}$ (henceforth referred to as Oak 450 and Oak 650, respectively). Particles were ground and sieved through $1 \mathrm{~mm}$ and $2 \mathrm{~mm}$ apertures until homogenous.

\subsection{Methods}

\subsubsection{Acid Treatment}

For char chemical modification, as-received analytical-grade reagents were used. Chars were prepared to particle size $<2 \mathrm{~mm}$ then weighed to $4 \mathrm{~g}$ and mixed with $2 \mathrm{~g}$ of $99 \%$ phosphoric acid in $20 \mathrm{~mL}$ distilled water. The mixtures were shaken briefly and left to stand for $24 \mathrm{~h}$ at room temperature after which the mixtures were heated for about $15 \mathrm{~h}$ at $80^{\circ} \mathrm{C}$ in an oven and rinsed with distilled water. Hydrochars and biochars were oven-dried at $80^{\circ} \mathrm{C}$ and $100{ }^{\circ} \mathrm{C}$, respectively.

For sulphuric acid treatment, $5 \mathrm{~g}$ of char $(\leq 2 \mathrm{~mm})$ was mixed with $100 \mathrm{~mL}$ of $0.1 \mathrm{M} \mathrm{H}_{2} \mathrm{SO}_{4}$ and heated for $3 \mathrm{~h}$ at $80^{\circ} \mathrm{C}$ after which treated chars were washed with distilled water until a stable $\mathrm{pH}$ was attained and oven-dried at $80-100{ }^{\circ} \mathrm{C}$.

$\mathrm{H}_{2} \mathrm{O}_{2}$ treatment involved soaking $2 \mathrm{~g}$ of char $(\leq 2 \mathrm{~mm})$ in $20 \mathrm{~mL}$ of $10 \% \mathrm{H}_{2} \mathrm{O}_{2}$ for $48 \mathrm{~h}$ at room temperature, followed by heating at $80{ }^{\circ} \mathrm{C}$ for $24 \mathrm{~h}$ and rinsing with distilled water until the $\mathrm{pH}$ was between $6-7$ for biochars or close to the hydrochars original $\mathrm{pH}$ before oven-drying at $80-100{ }^{\circ} \mathrm{C}$.

\subsection{2. $\mathrm{KOH}$ Treatment}

$\mathrm{KOH}$ treatment involved mixing $4 \mathrm{~g}$ of char $(\leq 2 \mathrm{~mm})$ in a solution of $2 \mathrm{~g} \mathrm{KOH}$ and $20 \mathrm{~mL}$ of distilled water. The mixture was stirred for $2 \mathrm{~h}$ at $75{ }^{\circ} \mathrm{C}$ with a magnetic stirrer. Treated chars were subsequently rinsed with $\mathrm{HCl}$ followed by distilled water until the leachate $\mathrm{pH}$ values ranged between 6-7 for biochars or close to the hydrochars original $\mathrm{pH}$, after which treated hydrochars and biochars were oven-dried for $2 \mathrm{~h}$ at $80^{\circ} \mathrm{C}$ and $100^{\circ} \mathrm{C}$, respectively.

\subsubsection{Agronomical Analysis}

Ultimate analyses of biochar and hydrochar samples were determined using a CHN Elemental Analyser (Flash 2000, Thermo Scientific, Waltham, MA, USA). Proximate analysis was performed using a muffle furnace and analysis of char $\mathrm{pH}, \mathrm{CEC}, \mathrm{N}_{2}$ BET, surface area, macro-, and micro-nutrient contents have been described elsewhere [23].

\subsubsection{Ammonium Sorption Tests}

Details of the batch ammonium adsorption tests have been provided in [24]. Briefly, $0.1 \mathrm{~g}$ of char $(\leq 850 \mu \mathrm{m})$ is mixed with $100 \mathrm{~mL}$ of either $43 \mathrm{mg}$ or $450 \mathrm{mg} \mathrm{NH}_{4}^{+} \mathrm{L}^{-1}$ solution (pH 7) prepared from ammonium chloride salt in deionised water. $\mathrm{NH}_{4}{ }^{+}$sorption capacities for the various treated chars were evaluated at $450 \mathrm{mg} \mathrm{NH}{ }_{4}^{+} \mathrm{L}^{-1}$ to investigate their potential for $\mathrm{NH}_{4}{ }^{+}$recovery from a representative concentration range encountered in real-case conditions. The mixture was shaken at $160 \mathrm{rpm}$ for $24 \mathrm{~h}$ at room temperature. To determine whether losses in $\mathrm{NH}_{4}{ }^{+}$occurred during sorption tests, the same procedure was performed without char addition. As only small amounts of $\mathrm{NH}_{4}{ }^{+}$were lost after sorption tests with such controls, reductions in $\mathrm{NH}_{4}{ }^{+}$after sorption tests were assumed to be entirely due to char sorption. Char $\mathrm{NH}_{4}{ }^{+}$sorption capacity was determined as:

$$
q_{e}=\left(C_{0}-C_{e}\right) \frac{V}{M}
$$

where $C_{0}$ and $C_{e}=$ initial and equilibrium ammonium adsorbate concentrations respectively $\left(\mathrm{mg} \mathrm{L}^{-1}\right)$; $V=$ volume of solution $(\mathrm{L}) ; M=$ mass of char $(\mathrm{g})$.

Batch desorption followed a similar procedure as outlined above, where adsorbed $\mathrm{NH}_{4}{ }^{+}$was extracted from chars using $0.01 \mathrm{M} \mathrm{KCl}$ and analysed by ion chromatography. This procedure was also 
performed on chars to determine their native $\mathrm{NH}_{4}{ }^{+}$contents to correct for any $\mathrm{NH}_{4}{ }^{+}$release from the initial char. Desorbability was determined as the ratio of desorbed $\mathrm{NH}_{4}{ }^{+}$to total adsorbed $\mathrm{NH}_{4}{ }^{+}$.

\subsubsection{Ammonia Sorption Test}

Ammonia adsorption was evaluated in a simple batch set-up, slightly modified from the methodology outlined in Taghizadeh-Toosi et al. [11]. Briefly, $60 \mathrm{~mL}$ of $\mathrm{NaOH}$ was transferred into a $250 \mathrm{~mL}$ Schott Duran bottle after which a weighing boat containing about $0.2 \mathrm{~g}$ char was carefully placed into the bottle so it floats on top of the solution. The bottle was fitted with a septa and closed to obtain a gas tight seal. Carefully, $25 \mathrm{~mL}$ of $0.05 \mathrm{M}\left(\mathrm{NH}_{4}\right)_{2} \mathrm{SO}_{4}$ was injected into the bottle through the septa and gaseous ammonia was produced via the following chemical reaction:

$$
2 \mathrm{NaOH}_{(\mathrm{aq})}+\left(\mathrm{NH}_{4}\right)_{2} \mathrm{SO}_{4(\mathrm{aq})} \rightarrow \mathrm{Na}_{2} \mathrm{SO}_{4(\mathrm{aq})}+2 \mathrm{H}_{2} \mathrm{O}_{(\mathrm{l})}+2 \mathrm{NH}_{3(\mathrm{~g})}
$$

$\mathrm{NaOH}$ was present in excess such that a known amount of gaseous $\mathrm{NH}_{3}$ was produced; in the current case this was $43 \mathrm{mg}$ of $\mathrm{NH}_{3}$ gas and average headspace volumes were equivalent to about $242.6 \mathrm{~mL}$. After seven days the samples were removed from the bottles and changes to nitrogen content were analysed via elemental analysis. The nitrogen content was adjusted for increased moisture content with respect to the char samples prior to $\mathrm{NH}_{3}$ sorption. Changes to $\mathrm{NH}_{4}{ }^{+}$content were also determined by ion chromatography after shaking a mixture of the char in a solution of $0.01 \mathrm{M} \mathrm{CaCl}_{2}$ in a 1:20 ratio for $2 \mathrm{~h}$ at $160 \mathrm{rpm}$. The $\mathrm{NH}_{3}$ sorption capacity of the raw holm oak biomass (from which the biochar and hydrochar were produced) was also evaluated following the same procedure outlined above for comparative purposes, since unprocessed feedstocks are often used as litter material for $\mathrm{NH}_{3}$ abatement in livestock systems. The $\mathrm{NH}_{3}$ sorption capacities of Oak 250 were further investigated at various concentrations of $\mathrm{NH}_{3}$ following the same procedure as outlined above, generating about 450,1000 , and $1500 \mathrm{mg} \mathrm{NH}_{3}$ by adjusting molar concentrations of $\left(\mathrm{NH}_{4}\right)_{2} \mathrm{SO}_{4}$ and $\mathrm{NaOH}$ according to Equation (2).

\subsubsection{Assessment of Error and Statistical Analysis}

Hydrothermal carbonization experiments were performed until repeatability of hydrochar yields was typically $\pm 3 \mathrm{wt} \%$. Whereas pyrolysis was performed by a commercial plant (Proininso S.A. Málaga, Spain), therefore, yields of biochar were unavailable. Biochar and hydrochar samples were both homogenized prior to use. All absorption tests were performed in duplicate, with selected data being performed in triplicate and products combined for a representative sample for analysis. Metal analysis and ultimate and proximate analysis were performed in duplicate until a maximum standard deviation of $\pm 2 \%$ was achieved. Mean values are reported together with standard error ranges and bars in tables and figures. Selected data for sorption of $\mathrm{NH}_{3}$ on modified chars was also analysed using a one-way ANOVA with a significance level $(\alpha=0.05)$, followed by a Tukey or Dunnett's test for examining each variable as separate. The value of $p<0.05$ was considered significant. Data for statistical analysis can be found in the Supplementary Materials.

\section{Results}

\subsection{Physicochemical Properties of Untreated Hydrochars and Biochars}

The unprocessed (as-received) bark-free oak wood possesses a low ash content of $2.6 \%$ and appreciable concentrations of $\mathrm{Ca}, \mathrm{K}, \mathrm{Mg}$, and $\mathrm{P}$. Its carbon content of $50.8 \%$ and molar $\mathrm{O} / \mathrm{C}$ ratio of 0.6 is within the range frequently reported for agricultural feedstocks. Following thermochemical treatment, a reduction in volatile matter content is evident while ash content increases (Figure 1). 


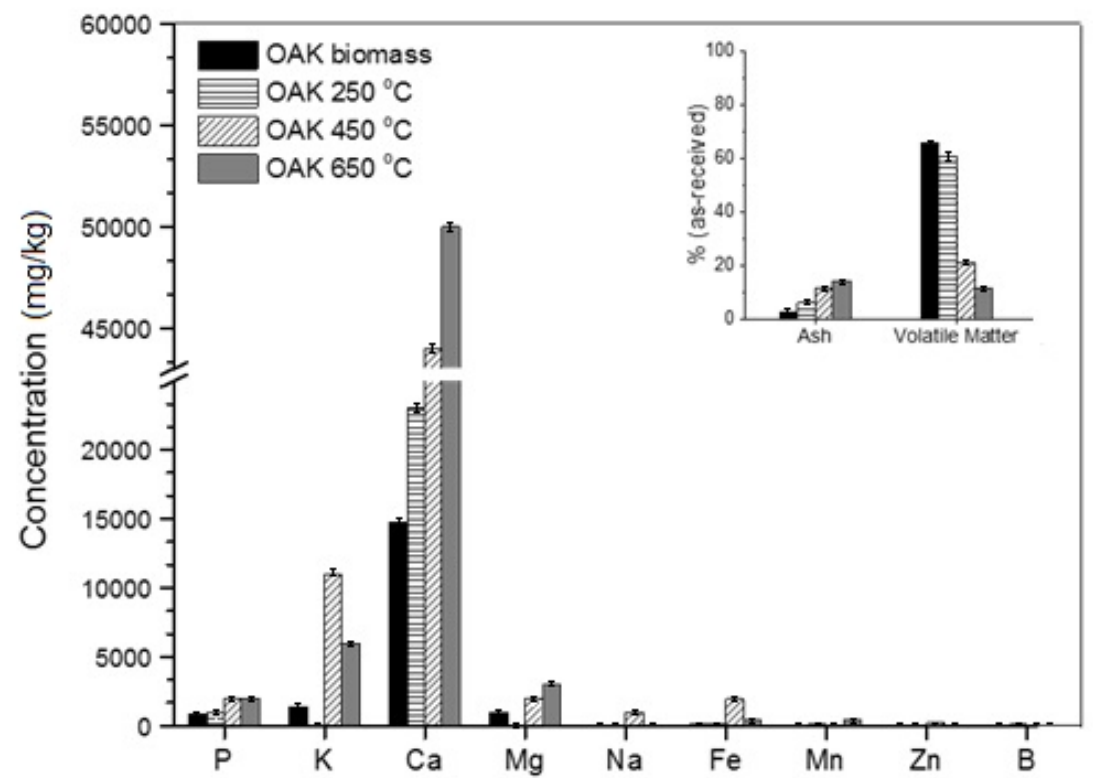

Figure 1. Distribution of the main micro- and macro-mineral contents within oak biomass, hydrochar, and biochars (mg/kg, dry basis). Inset: Ash and volatile content of oak biomass and chars (\%wt., as received basis). Based on duplicate data with repeatability typically within $\pm 2 \%$. Error bars represent deviation around the mean.

Other hydrochar and biochar physicochemical properties have been provided elsewhere [24], in which all carbon contents are $>50 \%$ in accordance with EBC and IBI product specification guidelines. Previous studies have observed that with increasing pyrolysis temperature, relative carbon contents increase and this is also observed in this study, with Oak 650 exhibiting the highest carbon content and surface area, the latter attributed to loss of volatiles with increasing temperature. Differences between the hydrochar and biochar properties are observed: $\mathrm{O} / \mathrm{C}$ ratios range from $0.2-0.4$ and are lowest for Oak 650. Differences in ash content and surface area are also observed with Oak 250 hydrochar having the lowest ash content $(6.2 \%)$ and surface area $\left(6 \mathrm{~m}^{2} \mathrm{~g}^{-1}\right)$ compared to biochar ash contents and surface areas of $11.7-14.3 \%$ and $180-280 \mathrm{~m}^{2} \mathrm{~g}^{-1}$, respectively. Oak 250 hydrochar also possesses the highest CEC as expected of a low temperature char [25] although this trend is not followed in the biochars since the CEC of Oak 650 is greater than Oak 450. A similar trend in biochar CEC was observed in Yuan et al. [26] and, to some extent, in Jassal et al. [27].

\section{2. $\mathrm{NH}_{3} / \mathrm{NH}_{4}{ }^{+}$Sorption by Untreated Hydrochar and Biochars}

The $\mathrm{NH}_{3}$ and $\mathrm{NH}_{4}{ }^{+}$sorption profiles of untreated oak biochars and hydrochars are presented in Figure 2 for concentrations equating to (a) $43 \mathrm{mg}$ and (b) $450 \mathrm{mg} \mathrm{NH}_{3} / \mathrm{NH}_{4}{ }^{+}$. The different conditions are used to assess the influence of the concentration of $\mathrm{N}$ species on sorption capacity and to simulate low to high levels of $\mathrm{N}$ species. The increase in total $\mathrm{N}$ content after exposure to $43 \mathrm{mg} \mathrm{NH}$ $11.0 \pm 0.4 \mathrm{mg} \mathrm{g}^{-1}$ for oak biomass and between $0.58-15.4 \mathrm{mg} \mathrm{g}^{-1}$ for the resulting chars. These levels are comparable to those reported in the literature; an average increment of $6.7 \pm 0.6 \mathrm{mg} \mathrm{g}^{-1}$ as reported by Taghizadeh-Toosi et al. [11].

Figure 2a shows that the \% sorption efficiency of $\mathrm{NH}_{3}$ is higher for the hydrochar than for both biochars ( $45 \%$ compared to $<10 \%$, respectively), equivalent to $18.8 \mathrm{mg} \mathrm{g}^{-1}$ for the hydrochar and $<3 \mathrm{mg} \mathrm{g}^{-1}$ for the biochars (Table 1). It is also worth noting that the performance of the raw biomass is comparable to that of the hydrochar at the lower levels of $\mathrm{NH}_{3}$ (Figure 2a) and is significantly higher than the biochar performance. This is less evident at higher $\mathrm{NH}_{3}$ levels (Figure 2b), however, the sorption efficiency of the raw biomass is still comparable with that of the biochars. $\mathrm{NH}_{3}$ sorption capacities of the raw feedstock and hydrochar are, in fact, comparable in spite of the lower mineral matter concentrations present in the former (Figure 1). While the \% sorption is lower with the higher 
initial $\mathrm{NH}_{3} / \mathrm{NH}_{4}{ }^{+}$concentration, the same general trend is observed for $\mathrm{NH}_{3}$ sorption with Oak 250 hydrochar retaining about $20.4 \mathrm{mg} \mathrm{g}^{-1}$ more $\mathrm{NH}_{3}$ than Oak 650 (Table 1). The sorption capacity is approximately a factor of 10 lower as expected.

(a)

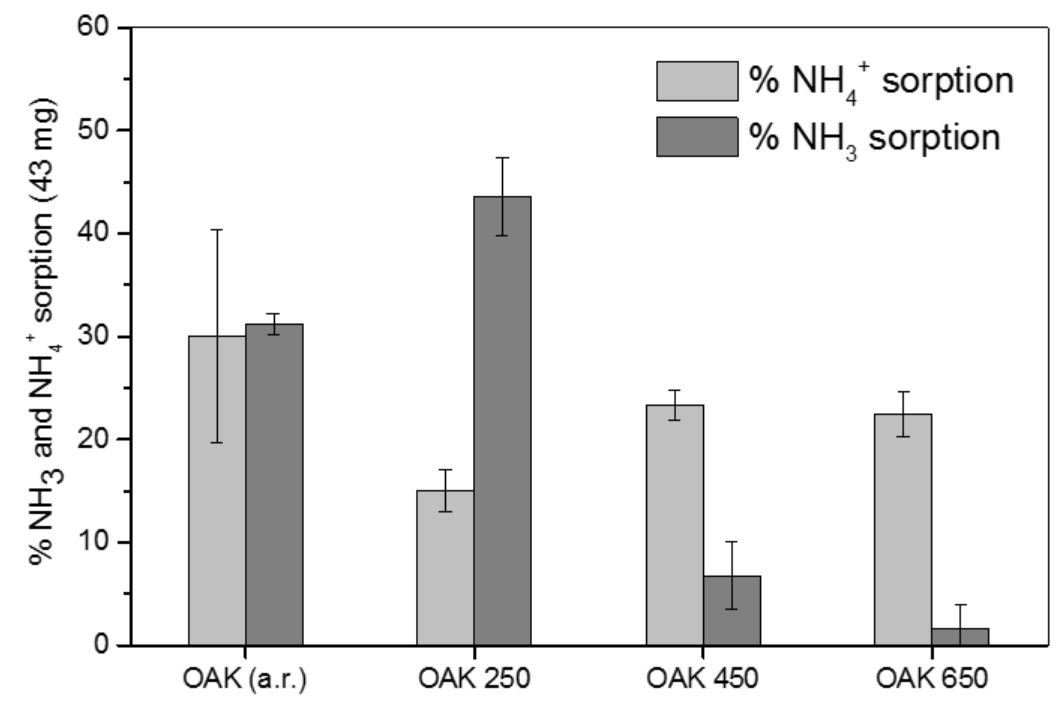

(b)

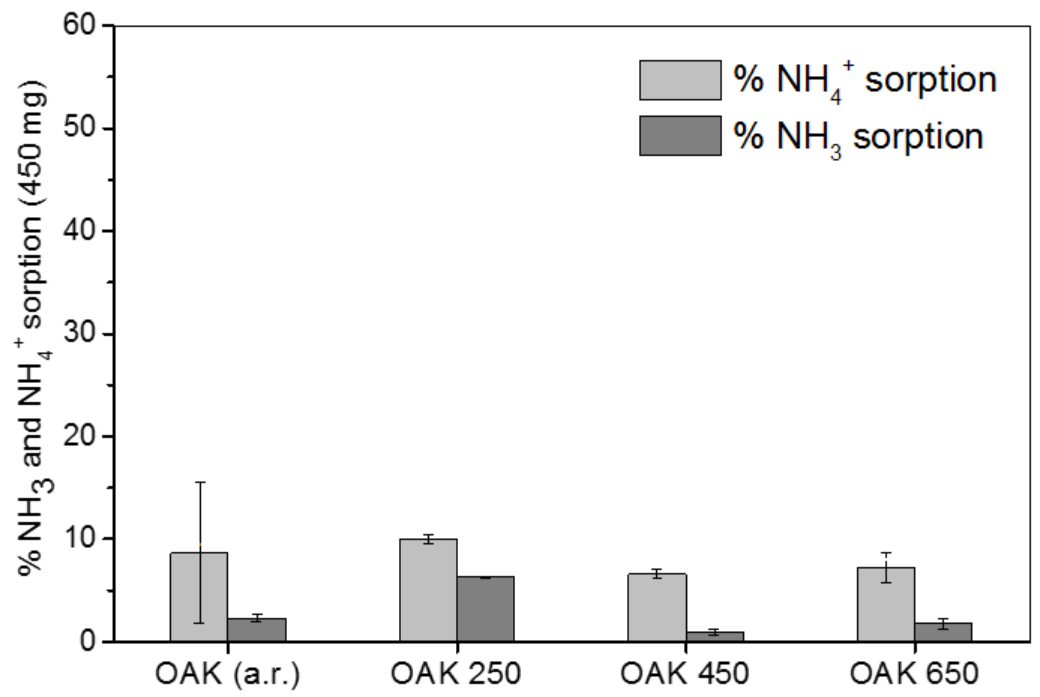

Figure 2. $\mathrm{NH}_{3}$ and $\mathrm{NH}_{4}{ }^{+}$removal efficiencies of unprocessed oak biomass (as received) and oak chars at approximately (a) $43 \mathrm{mg} \mathrm{NH} 3$ and $43 \mathrm{mg} \mathrm{NH}_{4}{ }^{+} \mathrm{L}^{-1}$ (b) $450 \mathrm{mg} \mathrm{NH}_{3}$ and $\mathrm{NH}_{4}{ }^{+} \mathrm{L}^{-1}$. Based on duplicate data and error bars represent deviation around the mean. 
Table 1. Char sorption and release profiles for gaseous $\mathrm{NH}_{3}$ and aqueous $\mathrm{NH}_{4}{ }^{+}$.

\begin{tabular}{|c|c|c|c|c|}
\hline Char & $\begin{array}{l}\mathrm{NH}_{3} \text { Sorption } \\
\quad\left(\mathrm{mg} \mathrm{g}^{-1}\right)\end{array}$ & $\begin{array}{c}\mathrm{CaCl}_{2} \text {-Extractable } \mathrm{NH}_{4}{ }^{+} \\
\left(\mathrm{mg} \mathrm{g}^{-1}\right)\end{array}$ & $\begin{array}{l}\mathrm{NH}_{4}+\text { Sorption } \\
\quad\left(\mathrm{mg} \mathrm{g}^{-1}\right)\end{array}$ & $\begin{array}{l}\mathrm{NH}_{4}{ }^{+} \text {Desorbed } \\
\left(\mathrm{mg} \mathrm{g}^{-1}\right)\end{array}$ \\
\hline & \multicolumn{2}{|c|}{ a $43 \mathrm{mg} \mathrm{NH}_{3}$} & \multicolumn{2}{|c|}{$43 \mathrm{mg} \mathrm{NH}_{4}^{+} \mathrm{L}^{-1}$} \\
\hline OAK 250 & $18.8 \pm 1.6$ & $7.2 \pm 0.3$ & $6.0 \pm 0.5$ & $0.0 \pm 0.0$ \\
\hline OAK 450 & $2.9 \pm 1.4$ & $1^{b}$ & $9.2 \pm 0.2$ & $1.1 \pm 1.6$ \\
\hline \multirow[t]{2}{*}{ OAK 650} & $0.7 \pm 0.9$ & $1^{b}$ & $8.9 \pm 0.8$ & $0.0 \pm 0.0$ \\
\hline & \multicolumn{2}{|c|}{ a $450 \mathrm{mg} \mathrm{NH}_{3}$} & \multicolumn{2}{|c|}{$450 \mathrm{mg} \mathrm{NH}_{4}^{+} \mathrm{L}^{-1}$} \\
\hline OAK 250 & $28.5 \pm 0.3$ & $6.1 \pm 0.8$ & $45.1 \pm 1.7$ & $9^{a}$ \\
\hline OAK 450 & $4.3 \pm 1.2$ & $2.68 \pm 0.04$ & $29.9 \pm 1.8$ & $12^{\mathrm{a}}$ \\
\hline OAK 650 & $8.1 \pm 2.2$ & $2.1 \pm 0.1$ & $32.7 \pm 6.7$ & $11^{\mathrm{a}}$ \\
\hline
\end{tabular}

a 43 and $450 \mathrm{mg} \mathrm{NH}_{3}$ generated based on Equation (2); ${ }^{\text {s single analyses reported while other values are reported as }}$ mean uptake \pm standard deviation; undetected $\mathrm{NH}_{4}{ }^{+}$concentrations reported as zero.

Figure 3 illustrates the $\mathrm{NH}_{3}$ sorption capacities for Oak 250 over a range of $\mathrm{NH}_{3}$ concentrations. The analysis was found to be statistically significant $\mathrm{F}(4,4)=60.57, p=0.00086$. A Tukey test was further implemented to demonstrate all the treatments were significantly different. The hydrochar shows a change in $\mathrm{NH}_{3}$ sorption with increasing $\mathrm{NH}_{3}$ concentration indicating that while a greater capacity is attained at higher initial $\mathrm{NH}_{3}$ concentration, the \% sorption capacity reduces substantially and suggests that while sites are available for $\mathrm{NH}_{3}$ sorption even at $1500 \mathrm{mg} \mathrm{NH}_{3}$, its removal efficiency is greatly reduced. $\mathrm{NH}_{3}$ sorption appears to start levelling off at higher concentration suggesting a maximum sorption in the order of about $45 \mathrm{mg} \mathrm{g}^{-1} \mathrm{NH}_{3}$ for the hydrochar.

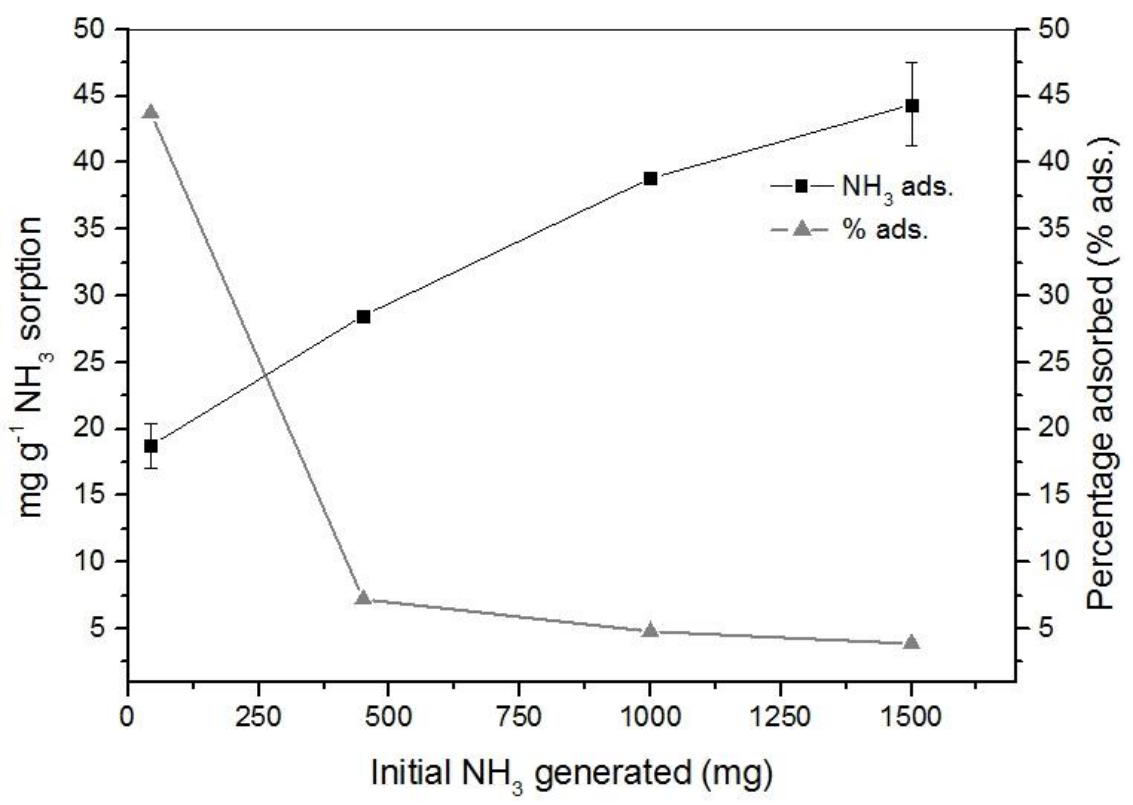

Figure 3. $\mathrm{NH}_{3}$ sorption capacities for Oak 250 hydrochar at 43, 450, 1000, and $1500 \mathrm{mg} \mathrm{NH}_{3}$ gas generated according to Equation (2). Error bars represent deviation around the mean. For statistical analysis please refer to Supplementary Material Table S3.

Subsequent washing of the chars in $\mathrm{CaCl}_{2}$ does not release the entire adsorbed $\mathrm{N}$ (Table 1). Typically, $30-40 \%$ of the $\mathrm{N}$ is released upon washing with $\mathrm{CaCl}_{2}$ in the form of $\mathrm{NH}_{4}{ }^{+}$. As observed by Taghizadeh-Toosi et al. [11,14], no changes in $\mathrm{NO}_{3}{ }^{-}$contents are observed in oak hydrochar or biochars following ammonia sorption tests. $\mathrm{CaCl}_{2}$-extractable ammonium contents are highest for the hydrochar and generally decrease in proportion to ammonia gas concentration exposure. Following exposure to 1000 and $1500 \mathrm{mg}$ gaseous $\mathrm{NH}_{3}$, only $6.7 \pm 0.3$ and $8.6 \pm 2.0 \mathrm{mg}$ of $\mathrm{NH}_{4}{ }^{+}$are respectively recoverable per gram of Oak 250 hydrochar. Taghizadeh-Toosi et al. [11] similarly observed that $2 \mathrm{M}$ 
$\mathrm{KCl}$-extractable $\mathrm{NH}_{4}{ }^{+}$represented only a fraction of the increase in char total $\mathrm{N}$ following exposure to $\mathrm{NH}_{3}$. As $\mathrm{CaCl}_{2}$-extractable ammonium is considered plant-available [28,29], these results suggest that hydrochar may be the most beneficial in terms of release of $\mathrm{N}$ in soils or soil amendment products. Further investigations are required to confirm whether more ammonium is recoverable with serial extractions using $2 \mathrm{M} \mathrm{KCl}$ and water [30], although $\mathrm{N}$ species other than inorganic $\mathrm{N}$ may be present in post- $\mathrm{NH}_{3}$ sorption chars [14] which are not easily recoverable with such extractants. For instance, Petit et al. [31] showed that ammonia retention in the form of amines is also possible. Studies by Thorn and Mikita [32] on ammonia fixation by organic matter, suggested that organic matter rich in phenolic and hydroxyl groups are capable of retaining ammonia in the form of heterocyclic nitrogen (indole, pyrrole, pyridine).

The $\mathrm{NH}_{4}{ }^{+}$sorption profiles for the hydrochar and biochars are also presented in Figure $2 \mathrm{a}, \mathrm{b}$ at initial concentrations $\left(C_{0}\right)$ of 43 and $450 \mathrm{mg} \mathrm{NH}_{4}{ }^{+} \mathrm{L}^{-1}$, respectively. Char $\mathrm{NH}_{4}{ }^{+}$removal efficiencies range from $15.1-23.3 \%$ at $43 \mathrm{mg} \mathrm{L}^{-1}$ and decrease to $6.6-10 \%$ at $450 \mathrm{mg} \mathrm{L}^{-1}$. The trends are less clear for the sorption of $\mathrm{NH}_{4}{ }^{+}$. There is less distinction between the different samples for $\mathrm{NH}_{4}{ }^{+}$sorption and there is little statistical difference between the raw biomass and the different chars. At lower levels of $\mathrm{NH}_{4}{ }^{+}$(Figure 2a), Oak 250 hydrochar demonstrates a lower capacity for $\mathrm{NH}_{4}{ }^{+}$sorption compared to $\mathrm{NH}_{3}$ whereas for the biochars, the opposite is true. For higher levels of $\mathrm{NH}_{4}{ }^{+}$(Figure $2 \mathrm{~b}$ ), the hydrochar sorption is comparable to that of the biochars. In both cases, the capacity of the chars for sorption of $\mathrm{NH}_{4}{ }^{+}$is higher than for $\mathrm{NH}_{3}$. This suggests that surface functionality is an important consideration in retention of $\mathrm{NH}_{3} / \mathrm{NH}_{4}{ }^{+}$. While the biochars have a higher surface area, this does not equate to a higher $\mathrm{NH}_{3}$ adsorption compared to the hydrochar, indicating that functionality is more important than surface area for $\mathrm{NH}_{3}$. The levels of $\mathrm{NH}_{4}{ }^{+}$sorption by the biochars increases over three-fold compared to $\mathrm{NH}_{3}$. This is thought to be related to the presence of mineral matter in the chars which is enhanced in the higher temperature biochars (Figure 1). The levels of inorganics in the chars are often attributed to higher levels of sorption. Zhang and Wang [33] recovered $>60 \%$ $\mathrm{NH}_{4}{ }^{+}$partly due to the biochar composites being enhanced with $\mathrm{Mg}$ and PIn this study, the higher temperature biochars contain higher levels of ash than the raw biomass and hydrochars, however, the raw biomass shows a significant level of sorption capacity compared to the hydrochars and biochars. Detailed analysis of the inorganic content of the chars and raw feedstock indicates there is no obvious correlation between $\% \mathrm{NH}_{4}{ }^{+}$sorption and char ash, $\mathrm{P}, \mathrm{Mg}$, or Ca content. $\mathrm{NH}_{4}{ }^{+}$release from chars are also low following desorption tests.

The levels of $\mathrm{NH}_{4}{ }^{+}$sorption in this study are comparable to reports in the literature for biochar. Wang et al. reported 12.1-16.1\% removal efficiencies of untreated and La-treated $300{ }^{\circ} \mathrm{C}$ biochars $\left(C_{0}=25.7 \mathrm{mg} \mathrm{NH}_{4}{ }^{+} \mathrm{L}^{-1}\right)$ [25]. Other studies have reported higher $\mathrm{NH}_{4}-\mathrm{N}$ removal efficiencies however: $37.3 \%$ sorption by activated phytoremediation plant char $\left(C_{0}=39 \mathrm{mg} \mathrm{NH}_{4}{ }^{+} \mathrm{L}^{-1}\right)$ in Zeng et al. [34] and $62-83 \%$ sorption by Brewer's grains-sewage sludge biochar $\left(C_{0}=100 \mathrm{mg} \mathrm{NH}_{4}^{+} \mathrm{L}^{-1}\right)$ in Zhang and Wang [33]. $0.01 \mathrm{M} \mathrm{KCl}$ was used to determine the readily recoverable $\mathrm{NH}_{4}{ }^{+}$post-sorption from the chars and a selected number were also extracted with $0.01 \mathrm{M} \mathrm{CaCl}_{2}$ to compare performance of both extractants. $\mathrm{NH}_{4}{ }^{+}$desorption was found to be $<10 \mathrm{mg} \mathrm{g}^{-1}$ in both cases thus the desorbability ratio ranged between a factor of $0.2-0.4$.

Previous studies have reported a positive relationship between $\mathrm{NH}_{4}{ }^{+}$sorption and char CEC, surface area, oxygen content and metal content [9,12,33-35]. In this study, $\mathrm{NH}_{4}{ }^{+}$sorption followed a similar trend to CEC, yet the amounts of $\mathrm{NH}_{4}{ }^{+}$retained by the chars at both 43 and $450 \mathrm{mg} \mathrm{NH}_{4}{ }^{+} \mathrm{L}^{-1}$ are substantially higher than predicted by their corresponding CEC values, recalculated as $\mathrm{NH}_{4}{ }^{+}$eq to estimate maximum theoretical $\mathrm{NH}_{4}{ }^{+}$sorption capacities (Table 2). Some studies have also observed that CEC underestimates $\mathrm{NH}_{4}{ }^{+}$sorption capacity $[14,27,34,36]$; this discrepancy has been attributed to physical sorption of $\mathrm{N}$ into the char pores as opposed to ion exchange [27], or to conversion of $\mathrm{NH}_{4}{ }^{+}$ into organic nitrogen [36]. Conversely, Nguyen and Tanner [37] observed maximum $\mathrm{NH}_{4}{ }^{+}$sorption by a zeolite to be substantially lower than the CEC-predicted values. 
Table 2. Elemental content and CEC values for a selection of treated chars.

\begin{tabular}{|c|c|c|c|c|c|c|c|}
\hline Char & CEC & b $\mathrm{NH}_{4}{ }^{+}$eq & $\mathrm{C}$ & $\mathbf{H}$ & $\mathbf{N}$ & $\mathbf{S}$ & ${ }^{\mathrm{a}} \mathrm{O}$ \\
\hline & $\left(\mathrm{cmolc} \mathrm{kg}^{-1}\right)$ & $\left(\mathrm{mg} \mathrm{g}^{-1}\right)$ & $(\%)$ & $(\%)$ & $(\%)$ & $(\%)$ & $(\%)$ \\
\hline OAK 250 & $88.3 \pm 9.7$ & 15.9 & 67.9 & 6.5 & 1.4 & 0.1 & 24.1 \\
\hline OAK250- $\mathrm{H}_{2} \mathrm{SO}_{4}$ & $81.1 \pm 4.7$ & 14.6 & 61.3 & 4.9 & 0.4 & 0.04 & 33.4 \\
\hline OAK $250-\mathrm{H}_{3} \mathrm{PO}_{4}$ & $86.8 \pm 4.7$ & 15.6 & 60.2 & 4.8 & 0.3 & 0 & 34.6 \\
\hline OAK $250-\mathrm{H}_{2} \mathrm{O}_{2}$ & $102.4 \pm 7.3$ & 18.4 & 56.1 & 4.5 & 0.3 & 0 & 39.1 \\
\hline OAK 250-KOH & $102.0 \pm 8.2$ & 18.4 & 62 & 4.9 & 0.4 & 0 & 32.7 \\
\hline OAK 450 & $59.4 \pm 8.1$ & 10.7 & 65.7 & 2.7 & 0.6 & 0 & 31 \\
\hline OAK $450-\mathrm{H}_{2} \mathrm{SO}_{4}$ & $66.3 \pm 15.6$ & 11.9 & 73.6 & 4.8 & 0.5 & 0 & 21.1 \\
\hline OAK $450-\mathrm{H}_{3} \mathrm{PO}_{4}$ & $103.5 \pm 33.0$ & 18.6 & 70 & 4.1 & 0.4 & 0 & 25.5 \\
\hline OAK $450-\mathrm{H}_{2} \mathrm{O}_{2}$ & $147.2 \pm 6.9$ & 26.5 & 71.3 & 3.9 & 0.5 & 0 & 24.3 \\
\hline OAK $450-\mathrm{KOH}$ & $141.0 \pm 13.2$ & 25.4 & 77.7 & 2.8 & 0.6 & 0 & 19 \\
\hline OAK 650 & $76.6 \pm 0.7$ & 13.8 & 76.5 & 1.4 & 0.8 & 0 & 21.3 \\
\hline OAK $650-\mathrm{H}_{2} \mathrm{SO}_{4}$ & $106.8 \pm 18.7$ & 19.2 & 62.9 & 2.4 & 0.6 & 0 & 34.2 \\
\hline OAK $650-\mathrm{H}_{3} \mathrm{PO}_{4}$ & $126.3 \pm 63.9$ & 22.7 & 50.5 & 3.6 & 0.5 & 0 & 45.4 \\
\hline OAK $650-\mathrm{H}_{2} \mathrm{O}_{2}$ & $71.2 \pm 7.4$ & 12.8 & 63.7 & 2.3 & 0.5 & 0 & 33.5 \\
\hline OAK 650-KOH & $132.3 \pm 11.2$ & 23.8 & 68.3 & 1.9 & 0.7 & 0 & 29.2 \\
\hline
\end{tabular}

a Oxygen content determined as difference between $\% \mathrm{C}, \mathrm{H}, \mathrm{N}$ and $\mathrm{S}$ from 100 (dry basis); ${ }^{\mathrm{b}} \mathrm{NH}_{4}{ }^{+}$eq refers to the maximum equivalent char $\mathrm{NH}_{4}{ }^{+}$sorption capacity since $1 \mathrm{cmol}_{\mathrm{C}} \mathrm{kg}^{-1}=0.18 \mathrm{mg} \mathrm{NH}_{4}{ }^{+} \mathrm{kg}^{-1}$ char; char. CEC expressed as average of duplicates \pm standard deviation.

\subsection{Physicochemical Properties of Modified Hydrochars and Biochars}

Table 2 lists the elemental content and CEC of the modified chars and indicates a decrease in carbon and nitrogen content for all the treatments of Oak 250 hydrochar and Oak 650, and a corresponding increase in oxygen content. The carbon content for the Oak 450 chars increase possibly due to the relative decrease of inorganic content following treatment [34,35] while oxygen contents decrease. These findings are in general agreement with Zheng et al. who observed increases in carbon, hydrogen, and nitrogen for acid-washed biochars with a corresponding decrease in oxygen content [38]. This anomaly could be related to the relative ease of leaching of inorganics and the difference in reactivity of the surface towards decarboxylation and hydrolysis. Similar observations were reported by Latham et al. after acid and base treatment during hydrothermal treatment of sucrose [39]. The nitrogen contents of the untreated chars are presented in Table S1 and range from 4.3-5.5 $\mathrm{mg} \mathrm{N} \mathrm{g}^{-1}$ char. The N contents of the treated chars generally decrease with the exception of $\mathrm{KOH}$ treated biochars, which result in slight increases in $\mathrm{N}$ (for example an increase in $\mathrm{N} \mathrm{d.3-6.3} \mathrm{mg} \mathrm{N} \mathrm{g}^{-1}$ for Oak 450 treated in $\mathrm{KOH}$ and 5.5-7.0 $\mathrm{mg} \mathrm{N} \mathrm{g}^{-1}$ for Oak 650 treated in $\mathrm{KOH}$ ). The relative increase in $\mathrm{N}$ content following $\mathrm{KOH}$ treatment is speculated to be primarily due to loss of carbon, while the reduction in $\mathrm{N}$ is possibly due to modification disrupting $\mathrm{N}$-containing compounds in the biomass thus increasing $\mathrm{N}$ release.

Acid treatment has varying effects on char CEC: the CEC of the treated hydrochars are generally higher than the biochars, due to increased surface functionality. There is little change in CEC for the hydrochar treated with $\mathrm{H}_{2} \mathrm{SO}_{4}$ and $\mathrm{H}_{3} \mathrm{PO}_{4}$, whereas all other treatments increase char CEC. For instance, following $\mathrm{H}_{2} \mathrm{O}_{2}$ treatment, a two-fold increase in the CEC of Oak 450 is observed although the increase for Oak 250 hydrochar is less. Previous studies $[40,41]$ have attributed this effect to an increase in oxygen functional groups resulting from the oxidation of aromatic carbon and an increase in carbonyl groups. What is also apparent is that the increase in CEC cannot be attributed to changes in surface area since $\mathrm{H}_{2} \mathrm{O}_{2}$ treatment results in a drastic reduction in surface area $(>50 \%)$ for both oak biochars [24].

Changes in functionality following char modification has been investigated using FTIR. The FTIR spectra can identify changes in the relative abundance of carbonyl, hydroxyl, and other reactive functional groups as shown in the Supplementary Material (Figure S1, Table S2). However, no major differences in functional group intensities are observed, suggesting that chemical treatment does not 
alter char functionality substantially. A slight relative increase in the intensity of carbonyl functional groups $\left(1700 \mathrm{~cm}^{-1}\right.$ ) is observed following $\mathrm{H}_{2} \mathrm{O}_{2}$ treatment.

\section{4. $\mathrm{NH}_{3} / \mathrm{NH}_{4}{ }^{+}$Sorption by Treated Hydrochar and Biochars}

The $\mathrm{NH}_{3}$ sorption capacities of the treated chars are shown in Figure 4 using a fixed concentration of $43 \mathrm{mg}$ of $\mathrm{NH}_{3}$. The $\mathrm{NH}_{3}$ sorption for Oak 250 hydrochar and modified hydrochar are shown in Figure 4a, for Oak 450 biochar in Figure $4 \mathrm{~b}$ and for Oak 650 biochar in Figure 4c. The results show that $\mathrm{NH}_{3}$ sorption is higher for the hydrochar than for the two biochar samples, in agreement with initial testing. There was a significant difference between the means of the different treatments $\mathrm{F}(4,5)=21.43$, $p=0.0024$. Treatment with $\mathrm{H}_{2} \mathrm{O}_{2}$ and $\mathrm{KOH}$ appear to have the largest impact on increasing $\mathrm{NH}_{3}$ sorption in Oak 250 hydrochar whereas, treatment with $\mathrm{H}_{2} \mathrm{SO}_{4}$ and $\mathrm{H}_{3} \mathrm{PO}_{4}$ have little impact on sorption capacity (Figure 4a). The individual evaluation with Dunnett's test demonstrated that the treatments with $\mathrm{H}_{2} \mathrm{SO}_{4}$ and $\mathrm{H}_{3} \mathrm{PO}_{4}$, do not exhibit a significant effect, whereas the treatments with $\mathrm{H}_{2} \mathrm{O}_{2}$ and $\mathrm{KOH}$ do exhibit a significant effect. Secondly, in the case of Oak 450 there was a significant difference between the means of the different treatments $\mathrm{F}(4,5)=12.10, p=0.0088$. Dunnett's test demonstrates that all the treatments $\left(\mathrm{H}_{2} \mathrm{SO}_{4}\right.$ and $\mathrm{H}_{3} \mathrm{PO}_{4}, \mathrm{H}_{2} \mathrm{O}_{2}$, and $\left.\mathrm{KOH}\right)$ exhibit a significant effect. Modification of Oak 450 with acid and peroxide appear to enhance sorption capacity resulting in a three-fold increase in $\mathrm{NH}_{3}$ sorption from about $6.8 \%$ to $20.5 \% \mathrm{NH}_{3}$ removal efficiency. Modification of Oak 650 produces negligible enhancement of sorption capacity with the exception of $\mathrm{H}_{3} \mathrm{PO}_{4}$ treatment which shows a four-fold enhancement. Thirdly, in the case of Oak 650 there was no significant difference between the means of the different treatments $\mathrm{F}(4,5)=1.88, p=0.2522$. Dunnett's test here demonstrates that none of the treatments exhibit a significant effect.

Increases in sorption capacity following acid treatment are expected and supported in the literature. The increase in $\mathrm{NH}_{3}$ sorption of $\mathrm{H}_{2} \mathrm{SO}_{4}$-treated biochars is in agreement with the findings of Petit et al. who showed that sulfur-containing groups may be as influential as oxygen functional groups for $\mathrm{NH}_{3}$ sorption [31]. Similar increases to $\mathrm{NH}_{3}$ sorption have been reported by Chou et al. and Ritz et al. [42,43]. Such increases likely result from the formation of recoverable ammonium sulphate salts on adsorbent sites possibly following similar reactions to those outlined in Chou et al. [42]. It is also likely that increasing $\mathrm{H}_{2} \mathrm{SO}_{4}$ concentration up to a certain point could enhance $\mathrm{NH}_{3}$ sorption capacity, based on findings of Chou et al. [42]. The increase in $\mathrm{NH}_{3}$ sorption of $\mathrm{H}_{3} \mathrm{PO}_{4}$ treated biochars is also in agreement with the findings of Oya and Iu. Acid-catalyzed hydrolysis of polymeric units in lignocellulosic materials and labile carbon in biochars result in ketone formation after $\mathrm{H}_{3} \mathrm{PO}_{4}$ treatment [44,45]. Additionally, the formation of ammonium complexes with $\mathrm{H}_{3} \mathrm{PO}_{4}$ may have occurred as observed by Oya and Iu whose extensive studies confirmed the presence of $\mathrm{NH}_{4} \mathrm{H}_{2} \mathrm{PO}_{4}$ and/or $\left(\mathrm{NH}_{4}\right)_{2} \mathrm{HPO}_{4}$ depending on $\mathrm{H}_{3} \mathrm{PO}_{4}$ loading ratio employed [46]. $\mathrm{H}_{2} \mathrm{O}_{2}$ treatment has a marked effect on $\mathrm{NH}_{3}$ sorption for the lower temperature chars with $\mathrm{H}_{2} \mathrm{O}_{2}$-treated Oak 250 and Oak 450 showing an increase compared to the control. Similarly, $\mathrm{H}_{2} \mathrm{O}_{2}$ modification performed by Gómez-Serrano et al. resulted in an increase in surface $\mathrm{OH}$ groups and with increasing treatment time, an increase in carbonyl groups [47]. Increases in $\mathrm{NH}_{3}$ sorption capacity following $\mathrm{H}_{2} \mathrm{O}_{2}$ treatment may therefore occur due to interactions between $\mathrm{NH}_{3}$ and additional carbonyl groups. Similarly, treatment of biochar in $\mathrm{KOH}$ can also increase the level of surface $\mathrm{OH}$ groups (Figure S1) which may account for the increases in $\mathrm{NH}_{3}$ sorption by $\mathrm{KOH}$ treated Oak 250 and 450 chars.

Figure 5 shows the $\mathrm{NH}_{4}{ }^{+}$sorption following modification. In general, modification of the chars results in either no difference in sorption capacity or a reduction in $\mathrm{NH}_{4}{ }^{+}$sorption capacity for all the chars investigated. This reduction in sorption capacity is particularly apparent for treatment with $\mathrm{H}_{2} \mathrm{O}_{2}$ and $\mathrm{KOH}$ treatment. There is some evidence of enhancement of sorption capacity using acid treatment, however when investigated further using ANOVA tests, there is no significant difference compared to the control. For all modified chars, the release of $\mathrm{NH}_{4}{ }^{+}$is also measured following extraction in $0.01 \mathrm{M} \mathrm{KCl}$. As observed for untreated chars, $\mathrm{NH}_{4}{ }^{+}$release from modified chars are also low following desorption tests. For instance, $\mathrm{KOH}$ treated Oak 450 and 650 released 8.5 and $9.7 \mathrm{mg} \mathrm{g}^{-1}$, respectively; 
$\mathrm{H}_{2} \mathrm{O}_{2}$ treated Oak 450 and Oak 650 released 9.4 and $6.7 \mathrm{mg} \mathrm{g}^{-1}$, respectively. As blank sorption tests performed alongside the sample char sorption tests show negligible $\mathrm{NH}_{4}{ }^{+}$losses, it is speculated that $\mathrm{NH}_{4}{ }^{+}$release from chars is low either due to strong interactions between $\mathrm{NH}_{4}{ }^{+}$and the chars.

(a)

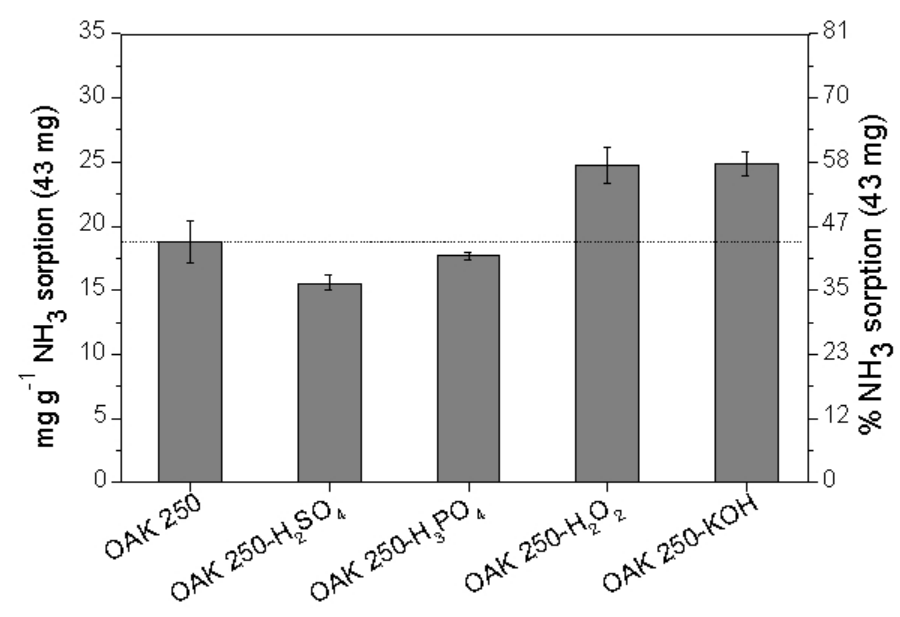

(b)

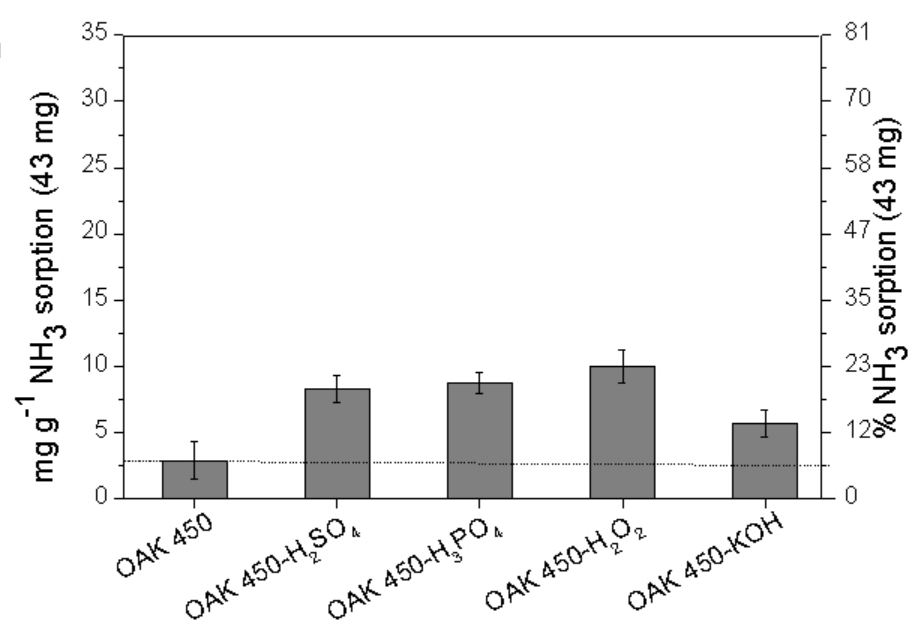

(c)

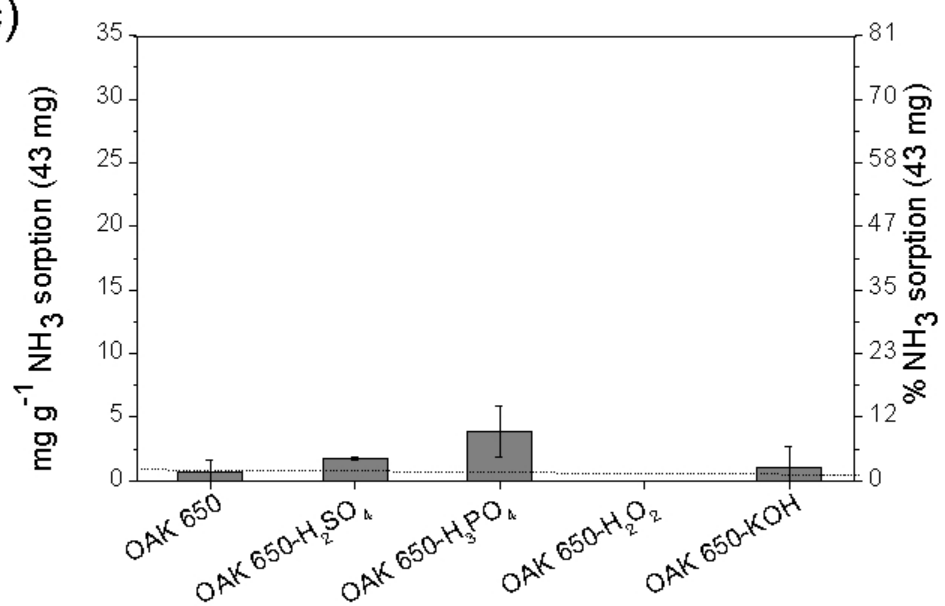

Figure 4. $\mathrm{NH}_{3}$ sorption by (a) treated oak $250{ }^{\circ} \mathrm{C}$ hydrochar; (b) treated oak $450{ }^{\circ} \mathrm{C}$ biochar; and (c) treated oak $650{ }^{\circ} \mathrm{C}$ biochar $\mathrm{d} 3 \mathrm{mg} \mathrm{NH}$ gas generated according to Equation (2). Error bars represent deviation around the mean. For statistical analysis please refer to Supplementary Material Tables S4-S6. 
(a)

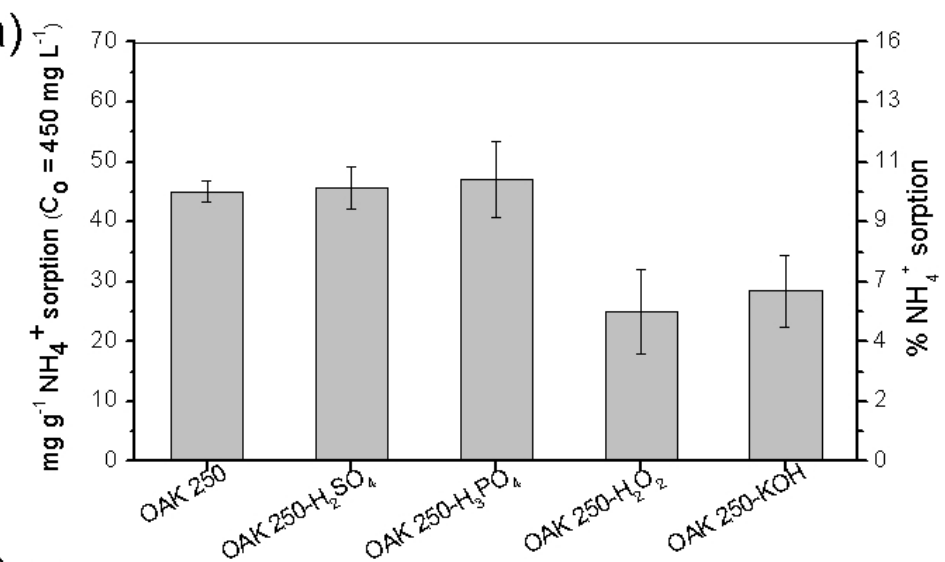

(b)

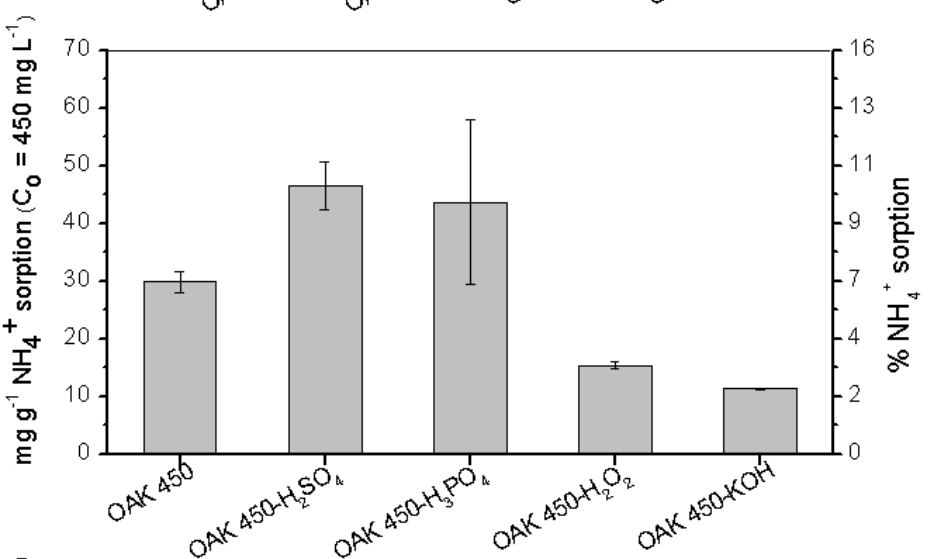

(c)

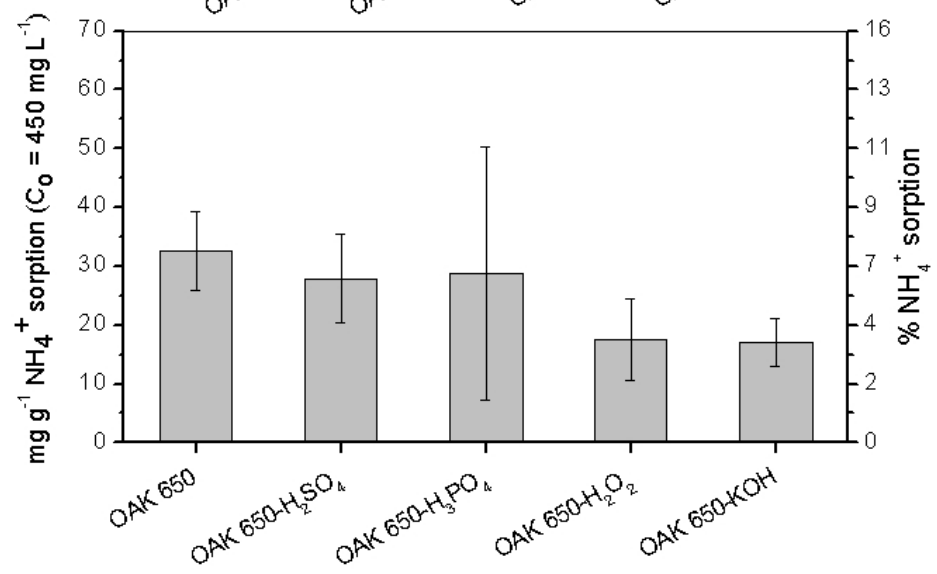

Figure 5. $\mathrm{NH}_{4}{ }^{+}$sorption by (a) treated Oak 250 hydrochar; (b) treated Oak 450 biochar; (c) treated Oak 650 biochar from $450 \mathrm{mg} \mathrm{NH}_{4}{ }^{+} \mathrm{L}^{-1}$ solution. Based on duplicate data, error bars represent deviation around the mean.

While treatment in $\mathrm{H}_{2} \mathrm{O}_{2}$ and $\mathrm{KOH}$ generally show the highest increase in CEC (Table 2), this is not reflected in sorption experiments. All oak chars experience a reduction in $\mathrm{NH}_{4}{ }^{+}$sorption following $\mathrm{KOH}$ and $\mathrm{H}_{2} \mathrm{O}_{2}$ treatment despite the substantial increases in char CEC (Figure 5). Huff et al. similarly noted that while $\mathrm{H}_{2} \mathrm{O}_{2}$ treatment increased CEC, methylene blue adsorption capacity decreased, which emphasises that CEC may not be a suitable predictor of char sorption capacity [40].

\section{Conclusions}

Results from this study show that oak hydrochars possess higher sorption capacities for gaseous $\mathrm{NH}_{3}$ and aqueous $\mathrm{NH}_{4}{ }^{+}$relative to their corresponding biochars. Post chemical modification of hydrochars and biochars has only limited effect on enhancing sorption capacities. Enhancement is more evident for $\mathrm{NH}_{3}$ sorption capacity than for $\mathrm{NH}_{4}{ }^{+}$sorption capacity which remains similar 
and in some cases is reduced compared to the control. Overall, the findings show that char surface functionality is more influential than surface area, thus, modification processes aimed at modifying the former are more beneficial in terms of char $\mathrm{NH}_{3}$ and $\mathrm{NH}_{4}{ }^{+}$sorption. Of the chemical treatments performed in this study, phosphoric acid appears to show the greatest potential for increasing both $\mathrm{NH}_{4}{ }^{+}$and $\mathrm{NH}_{3}$ sorption capacities of biochars. Treatment of hydrochars in $\mathrm{H}_{2} \mathrm{O}_{2}$ and $\mathrm{KOH}$ show potential for enhancement of $\mathrm{NH}_{3}$ sorption but result in a significant drop in $\mathrm{NH}_{4}{ }^{+}$sorption.

The ammonia batch set-up used in this study may be regarded as a useful tool for screening potential $\mathrm{NH}_{3}$ and $\mathrm{NH}_{4}{ }^{+}$adsorbents although benefits could also arise from the comparison of adsorbent performance in dynamic test conditions or in batch set-ups where humidity is better controlled.

Supplementary Materials: The following are available online at http://www.mdpi.com/2077-0472/9/1/16/s1, Figure S1. FTIR spectra of treated and untreated (a) OAK 250 (b) OAK 450, and (c) OAK 650 chars including unprocessed oak biomass (as received) $\left(4000-500 \mathrm{~cm}^{-1}\right.$; arbitrary $y$-axis values); Table S1. Char nitrogen content before and after exposure to $\mathrm{NH}_{3}$; Table S2. ATR-FTIR functional group assignment of prominent bands, Tables S3-S6: ANOVA analysis for Figures 3 and $4 \mathrm{a}-\mathrm{c}$, respectively.

Author Contributions: The authors contributed to this article in the following ways: Conceptualization: C.A.T., L.A.F., and A.B.R.; formal analysis: C.A.T., L.A.F., and A.B.R.; investigation: C.A.T.; supervision: L.A.F. and A.B.R.; visualization: C.A.T. and K.R.P.; writing—original draft: C.A.T.; writing—review and editing: K.R.P.

Funding: The authors would like to thank the EPSRC Centre for Doctoral Training in Bioenergy at the University of Leeds (EP/L014912/1) for financial support of Kiran Parmar. The Petroleum Technology Development Fund (PTDF) Nigeria for the financial support of Chibi Takaya and the Fertiplus Consortium (grant agreement no. 289853), co-funded by the European Commission, Directorate General for Research and Innovation, within the 7th Framework Programme of RTD, Theme 2-Biotechnologies, Agriculture and Food for the supply of biochar. The views and opinions expressed in this study are purely those of the authors and may not in any circumstances be regarded as stating an official position of the European Commission.

Acknowledgments: The authors wish to thank Surjit Singh and Patrick Biller for their analytical assistance and Simon Lloyd, Adrian Cunliffe, David Elliot, and Sheena Bennet for their technical assistance, including Jessica Quintana-Najera for the statistical analysis.

Conflicts of Interest: The authors declare no conflict of interest.

\section{References}

1. Arogo, J.; Westerman, P.W.; Heber, A.J. A review of ammonia emissions from confined swine feeding operations. Trans. Am. Soc. Agric. Eng. 2003, 46, 805. [CrossRef]

2. Kastner, J.R.; Miller, J.; Das, K.C. Pyrolysis conditions and ozone oxidation effects on ammonia adsorption in biomass generated chars. J. Hazard. Mater. 2009, 164, 1420-1427. [CrossRef] [PubMed]

3. Pollard, S.J.T.; Fowler, G.D.; Sollars, C.J.; Perry, R. Low-cost adsorbents for waste and wastewater treatment: A review. Sci. Total Environ. 1992, 116, 31-52. [CrossRef]

4. Steiner, C.; Das, K.C.; Melear, N.; Lakly, D. Reducing Nitrogen Loss during Poultry Litter Composting Using Biochar. J. Environ. Qual. 2010, 39, 1236-1242. [CrossRef] [PubMed]

5. Corre, Y.; Seredych, M.; Bandosz, T.J. Analysis of the chemical and physical factors affecting reactive adsorption of ammonia on graphene/nanoporous carbon composites. Carbon N. Y. 2013, 55, 176-184. [CrossRef]

6. Tran, H.N.; You, S.J.; Hosseini-Bandegharaei, A.; Chao, H.P. Mistakes and inconsistencies regarding adsorption of contaminants from aqueous solutions: A critical review. Water Res. 2017, 120, 88-116. [CrossRef] [PubMed]

7. Liang, P.; Yu, H.; Huang, J.; Zhang, Y.; Cao, H. The review on adsorption and removing ammonia nitrogen with biochar on its mechanism. MATEC Web Conf. 2016, 67, 07006. [CrossRef]

8. Zhang, S.; Yang, X.; Liu, L.; Ju, M.; Zheng, K. Adsorption behavior of selective recognition functionalized biochar to Cd(II) in wastewater. Materials (Basel) 2018, 11, 299. [CrossRef] [PubMed]

9. Le Leuch, L.M.; Bandosz, T.J. The role of water and surface acidity on the reactive adsorption of ammonia on modified activated carbons. Carbon N. Y. 2007, 45, 568-578. [CrossRef]

10. Petit, C.; Bandosz, T.J. Role of surface heterogeneity in the removal of ammonia from air on micro/mesoporous activated carbons modified with molybdenum and tungtsen oxides. Microporous Mesoporous Mater. 2009, 118, 61-67. [CrossRef] 
11. Taghizadeh-Toosi, A.; Clough, T.J.; Sherlock, R.R.; Condron, L.M. Biochar adsorbed ammonia is bioavailable. Plant Soil 2012, 350, 57-69. [CrossRef]

12. Canals-Batlle, C.; Ros, A.; Lillo-Ródenas, M.A.; Fuente, E.; Montes-Morán, M.A.; Martin, M.J.; Linares-Solano, A. Carbonaceous adsorbents for $\mathrm{NH}_{3}$ removal at room temperature. Carbon N. Y. 2008, 46, 176-178. [CrossRef]

13. Yin, X.; Han, H.; Gunji, I.; Endou, A.; Cheettu Ammal, S.S.; Kubo, M.; Miyamoto, A. $\mathrm{NH}_{3}$ Adsorption on the Brönsted and Lewis Acid Sites of $\mathrm{V}_{2} \mathrm{O}_{5}$ (010): A Periodic Density Functional Study. J. Phys. Chem. B 1999, 103, 4701-4706. [CrossRef]

14. Taghizadeh-Toosi, A.; Clough, T.J.; Sherlock, R.R.; Condron, L.M. A wood based low-temperature biochar captures $\mathrm{NH}_{3}-\mathrm{N}$ generated from ruminant urine-N, retaining its bioavailability. Plant Soil 2012, 353, 73-84. [CrossRef]

15. Ro, K.; Lima, I.; Reddy, G.; Jackson, M.; Gao, B. Removing Gaseous $\mathrm{NH}_{3}$ Using Biochar as an Adsorbent. Agriculture 2015, 5, 991-1002. [CrossRef]

16. Wang, Z.; Guo, H.; Shen, F.; Yang, G.; Zhang, Y.; Zeng, Y.; Wang, L.; Xiao, H.; Deng, S. Biochar produced from oak sawdust by Lanthanum (La)-involved pyrolysis for adsorption of ammonium $\left(\mathrm{NH}_{4}^{+}\right)$, nitrate $\left(\mathrm{NO}^{3-}\right)$, and phosphate $\left(\mathrm{PO}_{4}{ }^{3-}\right)$. Chemosphere 2015, 119, 646-653. [CrossRef]

17. Zheng, W.; Sharma, B.K.; Rajagopalan, N. Using Biochar as a Soil Amendment for Sustainable Agriculture. 2010. Available online: http:/ / hdl.handle.net/2142/25503 (accessed on 10 September 2018).

18. Gao, F.; Xue, Y.; Deng, P.; Cheng, X.; Yang, K. Removal of aqueous ammonium by biochars derived from agricultural residuals at different pyrolysis temperatures. Chem. Speciat. Bioavailab. 2015, 27, 92-97. [CrossRef]

19. Zheng, X.; Yang, Z.; Xu, X.; Dai, M.; Guo, R. Characterization and ammonia adsorption of biochar prepared from distillers' grains anaerobic digestion residue with different pyrolysis temperatures. J. Chem. Technol. Biotechnol. 2018, 93, 198-206. [CrossRef]

20. Ismadji, S.; Tong, D.S.; Soetaredjo, F.E.; Ayucitra, A.; Yu, W.H.; Zhou, C.H. Bentonite hydrochar composite for removal of ammonium from Koi fish tank. Appl. Clay Sci. 2016, 119, 146-154. [CrossRef]

21. Schimmelpfennig, S.; Müller, C.; Grünhage, L.; Koch, C.; Kammann, C. Biochar, hydrochar and uncarbonized feedstock application to permanent grassland-Effects on greenhouse gas emissions and plant growth. Agric. Ecosyst. Environ. 2014, 191, 39-52. [CrossRef]

22. Subedi, R.; Kammann, C.; Pelissetti, S.; Taupe, N.; Bertora, C.; Monaco, S.; Grignani, C. Does soil amended with biochar and hydrochar reduce ammonia emissions following the application of pig slurry? Eur. J. Soil Sci. 2015, 66, 1044-1053. [CrossRef]

23. Takaya, C.A.; Fletcher, L.A.; Singh, S.; Okwuosa, U.C.; Ross, A.B. Recovery of phosphate with chemically modified biochars. J. Environ. Chem. Eng. 2016, 4, 1156-1165. [CrossRef]

24. Takaya, C.A.; Fletcher, L.A.; Singh, S.; Anyikude, K.U.; Ross, A.B. Phosphate and ammonium sorption capacity of biochar and hydrochar from different wastes. Chemosphere 2016, 145, 518-527. [CrossRef] [PubMed]

25. Tan, X.; Liu, Y.; Zeng, G.; Wang, X.; Hu, X.; Gu, Y.; Yang, Z. Application of biochar for the removal of pollutants from aqueous solutions. Chemosphere 2015, 125, 70-85. [CrossRef] [PubMed]

26. Yuan, J.H.; Xu, R.K.; Zhang, H. The forms of alkalis in the biochar produced from crop residues at different temperatures. Bioresour. Technol. 2011, 102, 3488-3497. [CrossRef] [PubMed]

27. Jassal, R.S.; Johnson, M.S.; Molodovskaya, M.; Black, T.A.; Jollymore, A.; Sveinson, K. Nitrogen enrichment potential of biochar in relation to pyrolysis temperature and feedstock quality. J. Environ. Manag. 2015, 152, 140-144. [CrossRef]

28. Houba, V.J.G.; Novozamsky, I.; Huybregts, A.W.M.; van der Lee, J.J. Comparison of soil extractions by 0.01 $\mathrm{M} \mathrm{CaCl}_{2}$, by EUF and by some conventional extraction procedures. Plant Soil 1986, 96, 433-437. [CrossRef]

29. Lazányi, J.; Loch, J. Evaluation of $0.01 \mathrm{M} \mathrm{CaCl}_{2}$ Extractable Nitrogen Forms in a Long-term Experiment. Agrokémia és Talajt. 2006, 55, 135-144. [CrossRef]

30. Wang, B.; Lehmann, J.; Hanley, K.; Hestrin, R.; Enders, A. Adsorption and desorption of ammonium by maple wood biochar as a function of oxidation and pH. Chemosphere 2015, 138, 120-126. [CrossRef]

31. Petit, C.; Kante, K.; Bandosz, T.J. The role of sulfur-containing groups in ammonia retention on activated carbons. Carbon N. Y. 2010, 48, 654-667. [CrossRef]

32. Thorn, K.A.; Mikita, M.A. Ammonia fixation by humic substances: A nitrogen-15 and carbon-13 NMR study. Sci. Total Environ. 1992, 113, 67-87. [CrossRef] 
33. Zhang, J.; Wang, Q. Sustainable mechanisms of biochar derived from brewers' spent grain and sewage sludge for ammonia-nitrogen capture. J. Clean. Prod. 2016, 112, 3927-3934. [CrossRef]

34. Zeng, Z.; Zhang, S.; Li, T.; Zhao, F.; He, Z.; Zhao, H.; Yang, X.; Wang, H.; Zhao, J.; Rafiq, M.T. Sorption of ammonium and phosphate from aqueous solution by biochar derived from phytoremediation plants. J. Zhejiang Univ. Sci. B 2013, 14, 1152-1161. [CrossRef] [PubMed]

35. Gai, X.; Wang, H.; Liu, J.; Zhai, L.; Liu, S.; Ren, T.; Liu, H. Effects of feedstock and pyrolysis temperature on biochar adsorption of ammonium and nitrate. PLoS ONE 2014, 9, e113888. [CrossRef]

36. Bolan, N.S.; Saggar, S.; Luo, J.; Bhandral, R.; Singh, J. Gaseous Emissions of Nitrogen from Grazed Pastures: Processes, Measurements and Modelling, Environmental Implications, and Mitigation. Adv. Agron. 2004, $84,120$.

37. Nguyen, M.L.; Tanner, C.C. Ammonium removal from wastewaters using natural New Zealand zeolites. N. Z. J. Agric. Res. 1998, 41, 427-446. [CrossRef]

38. Zheng, H.; Wang, Z.; Zhao, J.; Herbert, S.; Xing, B. Sorption of antibiotic sulfamethoxazole varies with biochars produced at different temperatures. Environ. Pollut. 2013, 181, 60-67. [CrossRef]

39. Latham, K.G.; Jambu, G.; Joseph, S.D.; Donne, S.W. Nitrogen doping of hydrochars produced hydrothermal treatment of sucrose in $\mathrm{H}_{2} \mathrm{O}, \mathrm{H}_{2} \mathrm{SO}_{4}$, and $\mathrm{NaOH}$. ACS Sustain. Chem. Eng. 2014, 2, 755-764. [CrossRef]

40. Huff, M.D.; Lee, J.W. Biochar-surface oxygenation with hydrogen peroxide. J. Environ. Manag. 2016, 165, 17-21. [CrossRef]

41. Liang, B.; Lehmann, J.; Solomon, D.; Kinyangi, J.; Grossman, J.; O’Neill, B.; Skjemstad, J.O.; Thies, J.; Luizão, F.J.; Petersen, J.; et al. Black Carbon Increases Cation Exchange Capacity in Soils. Soil Sci. Soc. Am. J. 2006, 70, 1719-1730. [CrossRef]

42. Chou, L.H.; Tsai, R.I.; Chang, J.R.; Lee, M.T. Regenerable adsorbent for removing ammonia evolved from anaerobic reaction of animal urine. J. Environ. Sci. (China) 2006, 18, 1176-1181. [CrossRef]

43. Ritz, C.W.; Tasistro, A.S.; Kissel, D.E.; Fairchild, B.D. Evaluation of surface-applied char on the reduction of ammonia volatilization from broiler litter. J. Appl. Poult. Res. 2011, 20, 240-245. [CrossRef]

44. Lin, Y.; Munroe, P.; Joseph, S.; Henderson, R.; Ziolkowski, A. Water extractable organic carbon in untreated and chemical treated biochars. Chemosphere 2012, 87, 151-157. [CrossRef] [PubMed]

45. Marsh, H.; Rodríguez-Reinoso, F. Chapter 5-Activation Processes (Thermal or Physical). Activated Carbon; Elsevier Science Ltd.: Oxford, UK, 2006; pp. 243-321.

46. Oya, A.; Iu, W.G. Deodorization performance of charcoal particles loaded with orthophosphoric acid against ammonia and trimethylamine. Carbon N. Y. 2002, 40, 1391-1399. [CrossRef]

47. Gómez-Serrano, V.; Acedo-Ramos, M.; López-Peinado, A.J.; Valenzuela-Calahorro, C. Oxidation of activated carbon by hydrogen peroxide. Study of surface functional groups by FT-ir. Fuel 1994, 73, 387-395. [CrossRef] 